\title{
Rooting and weaning of apple rootstock YP
}

\author{
M Uosukainen \\ Agricultural Research Centre of Finland, Laukaa Research and Elite Plant Unit, SF-41340 Laukaa, Finland
}

(COST Meeting, 21-23 May 1992, Dijon, France)

\begin{abstract}
Summary - Rooting and weaning of the Finnish apple rootstock YP were studied. Rooting was affected by carbohydrate type of the in vitro medium and age of the shoots. The highest rooting rate was achieved when either $30 \mathrm{~g} / \mathrm{l}$ sucrose or glucose was used in the rooting medium and shoots were maintained for 5-7 wk on proliferation medium. Shoots $>7$ wk rapidly lost their ability to root. In preliminary experiments VA-mycorrhizal inoculation had a positive effect on growth during weaning and subsequent development in the greenhouse.
\end{abstract}

in vitro rooting / Malus / carbohydrates / VAM inoculation

Résumé - L'enracinement et le sevrage du porte-greffe de pommier finnois YP. L'enracinement et le sevrage du porte-greffe finnois YP ont été étudiés. L'enracinement est influencé par le glucide du milieu et l'âge des tiges. Le meilleur taux d'enracinement a été obtenu avec du sucrose ou du glucose à $30 \mathrm{~g} / \mathrm{l}$ dans le milieu d'enracinement et quand les tiges ont été conservées pendant 5-7 semaines sur le milieu de prolifération. Les tiges plus vieilles que 7 semaines perdent rapidement leur aptitude à s'enraciner. Dans des essais préliminaires, l'inoculation par des mycorrhizes vasculaires arbusculaires a eu un effet positif sur la croissance pendant le sevrage et sur le développement ultérieur en serre.

\section{enracinement in vitro / pommier = Malus / glucide / inoculation de mycorrhizes vasculaires arbusculaires}

\section{INTRODUCTION}

Research on micropropagation of apple trees started > 20 yr ago (Elliot, 1972; Walkey, 1972). Even though micropropagation of apple trees was in most cases successful, rooting of propagules often seemed to be problematic. Wounding of microcuttings, liquid culture (Sriskandarajah and Mullins, 1981) and use of phloroglucinol (James and Thurbon, 1979) have been studied but none of these methods has solved the basic problems related to apple rooting.

The frost-hardy Finnish apple rootstock YP, originating from an open-pollinated seedling of a Siberian crab apple (Malus baccata (L) Moench) (Säkö, 1977), has been considered difficult to propagate in vitro as a rootstock. At the Elite Plant Unit, rootstock YP has been used as a model plant in studies related to latent bacterial contaminants in tissue cultures and factors affecting rooting and weaning of micropropagated apple shoots. In this study, the effects of different carbohydrates and KIBA concentrations during in vitro rooting, the optimal age of the shoots and the effects of VAM inoculation were investigated.

\section{MATERIALS AND METHODS}

In all experiments the temperature was maintained at $24^{\circ} \mathrm{C}$ during the 16 -h light period and $21^{\circ} \mathrm{C}$ during the 8-h dark period. All shoots were produced by culturing them for $6-7$ wk on $G$ medium (table I) containing 20 $\mathrm{g} / \mathrm{l}$ fructose, $0.75 \mathrm{mg} / \mathrm{l}$ BAP (6-benzylaminopurine, Sig$\mathrm{ma}$ ) and $0.4 \mathrm{mg} / \mathrm{I}$ IBA (indole-3-butyric acid, Sigma). The light source consisted of a combination of fluorescent lamps Warm White Super and Floralux, $\approx 3500$ 3700 lux in the tubes ( 6500 lux above the tubes). The harvested shoots were $26-32 \mathrm{~mm}$ in length. Hormone treatments for rooting were given by immersing the shoots for 15-20 min. After the bath, shoots were placed on hormone-free rooting medium (table I) either in test tubes $(160 \times 20 \mathrm{~mm})$ or in Sigma's Phytatray II. The rooting experiments were performed using 80 shoots/treatment in 4 repeats.

During in vitro rooting, the effects of fructose, glucose and sucrose $(30 \mathrm{~g} / \mathrm{l})$ were compared using 4 different KIBA (potassium salt of IBA, Sigma) concentrations $(25,50,100$ and $200 \mathrm{mg} / \mathrm{l})$ together with $50 \mathrm{mg} / \mathrm{l}$ boric acid (Dirr and Heuser, 1987). Hormone treatment 
Table I. G basal medium used in propagation and rooting of apple rootstock YP. This medium was originally developed for strawberry micropropagation.

\begin{tabular}{|c|c|c|c|c|}
\hline \multirow{2}{*}{$\begin{array}{l}\text { Chemical } \\
\text { compounds }\end{array}$} & \multicolumn{4}{|c|}{ Amounts of chemicals used during: } \\
\hline & \multicolumn{2}{|c|}{ Proliferation } & \multicolumn{2}{|l|}{ Rooting } \\
\hline $\mathrm{NH}_{4} \mathrm{NO}_{3}$ & 1650 & $\mathrm{mg} / \mathrm{l}$ & 825 & $\mathrm{mg} / \mathrm{l}$ \\
\hline $\mathrm{KNO}_{3}$ & 250 & $"$ & 125 & \\
\hline $\mathrm{Ca}\left(\mathrm{NO}_{3}\right) 2.4 \mathrm{H}_{2} \mathrm{O}$ & 1000 & $"$ & 500 & $"$ \\
\hline $\mathrm{KH}_{2} \mathrm{PO}_{4}$ & 250 & $"$ & 250 & $"$ \\
\hline $\mathrm{MgSO}_{4} \cdot 7 \mathrm{H}_{2} \mathrm{O}$ & 200 & $"$ & 200 & $"$ \\
\hline $\mathrm{H}_{3} \mathrm{BO}_{3}$ & 6.2 & $"$ & 6.2 & $"$ \\
\hline $\mathrm{CoCl}_{2} \cdot 6 \mathrm{H}_{2} \mathrm{O}$ & 0.025 & $"$ & 0.025 & $"$ \\
\hline $\mathrm{CuSO}_{4} .5 \mathrm{H}_{2} \mathrm{O}$ & 0.025 & $"$ & 0.025 & $"$ \\
\hline $\mathrm{KI}$ & 0.83 & $"$ & 0.83 & $"$ \\
\hline $\mathrm{MnSO}_{4} \cdot 4 \mathrm{H}_{2} \mathrm{O}$ & 22.3 & $"$ & 22.3 & $"$ \\
\hline $\mathrm{NaMoO}_{4} \cdot 2 \mathrm{H}_{2} \mathrm{O}$ & 0.25 & $"$ & 0.25 & $"$ \\
\hline $\mathrm{ZnSO}_{4} \cdot 4 \mathrm{H}_{2} \mathrm{O}$ & 8.6 & $"$ & 8.6 & $"$ \\
\hline $\mathrm{Fe}(\mathrm{II}) \mathrm{Na}$-EDTA & 40.0 & $"$ & 40.0 & $"$ \\
\hline Nicotinic acid & 0.5 & $"$ & 0.5 & $"$ \\
\hline Thiamine & 1.0 & $"$ & 1.0 & $"$ \\
\hline Pyridoxine & 0.5 & $"$ & 0.5 & $"$ \\
\hline Glycine & 2.0 & $"$ & 2.0 & $"$ \\
\hline Myo-inositol & 100.0 & $"$ & 100.0 & $"$ \\
\hline $\mathrm{pH}$ & 5.0 & & 5.0 & \\
\hline Roth's agar & 4.5 & $g / l$ & 8.5 & $g / l$ \\
\hline Agar Ph Nord & 4.0 & $"$ & - & \\
\hline Bactopeptone & 0.27 & $"$ & 0.27 & $g / l$ \\
\hline
\end{tabular}

with the water-soluble KIBA together with boric acid was chosen instead of alcohol-soluble IBA to avoid possible injurious effects caused by the alcohol solvent. Rooting was evaluated after 3 and 5 wk on rooting medium. Survival during weaning and subsequent growth was observed. The effect of VAM-inoculation was studied by inoculating the in vitro rooted shoots with 3 different Finnish VAM isolates when the plants were transplanted to greenhouse conditions. The effect of VAM-inoculation was estimated 3 months after inoculation.

The correct timing for harvesting shoots was studied by rooting shoots which had been on proliferation medium for 4-10 wk. In this experiment, shoots were immersed in a $100 \mathrm{mg} / \mathrm{IBA}$ solution and then placed on the hormone-free rooting medium containing $30 \mathrm{~g} / \mathrm{l}$ sucrose. Rooting after 3 and 5 wk and survival during weaning were observed.

The effect of light quality on in vitro rooting was studied by rooting 6-wk-old shoots; the data have not been presented in this study. The lamp types compared were: 1) Fluora L58W/77 (Osram); 2) Gro-lux F58W/Gro (Sylvania GTE); 3) Cool White Super L58W-2T (Oy Airam Ab); 4) Warm White Super L58W3T (Oy Airam Ab); 5) Floralux L65/80 W-Fx (Oy Airam $A b)$; and 6) a combination of Warm White Super and
Floralux. The best rooting rate was obtained by using Warm White Super and Floralux together. This combination was therefore used as the light source in all experiments.

\section{RESULTS}

On average, sucrose was found to be the best carbohydrate for rooting (fig 1). The optimal hormone concentration varied according to the carbohydrate type used. The mean rooting rate for all KIBA treatments was $60 \%$ on sucrosecontaining medium, $38 \%$ on glucose and $15 \%$ on fructose-containing medium. The best rooting rate on sucrose was $72 \%$ when $25 \mathrm{mg} / \mathrm{l} \mathrm{KIBA}$ was used. In another experiment where KIBA was replaced by IBA, the average rooting rate was $75 \%$ on sucrose, $72 \%$ on glucose and $25 \%$ on fructose and in this case the difference between sucrose and glucose was not significant. Weaning survival in this material varied from $0-$ $96 \%$. The best weaning was obtained with shoots originated from sucrose containing medium. The roots regenerated on glucose media seemed to be poorly connected to the vascular bundle of the stems. Shoots from fructosecontaining media died during the weaning stage.

The best time for harvesting the shoots was when shoots had been on proliferation medium for 5-7 wk (fig 2). The best rooting (85\%) and highest weaning survival were obtained with 6wk-old shoots.

After VAM inoculation, growth of the young plants was significantly improved in comparison to the controls. The average height of the nontreated controls was $25 \mathrm{~mm}$, and plants inoculated with Glomus claroideum V43a, $94 \mathrm{~mm}$, with $G$ intraradix V104, $73 \mathrm{~mm}$ and with $G$ spp V43a $+\mathrm{V} 104,63 \mathrm{~mm}$. In this experiment, VAM inoculation did not improve the weaning survival of the shoots.

\section{DISCUSSION AND CONCLUSION}

Although micropropagated apple shoots are difficult to root, they are not unable to root. The type of carbohydrate utilised during the rooting stage together with auxin treatment were essential to the rooting success. These factors have also been reported in earlier works (George and Sherrington, 1984; Pua and Chong, 1984; Nemeth, 1986; Yae et al, 1986; Chauvin and Salesses, 


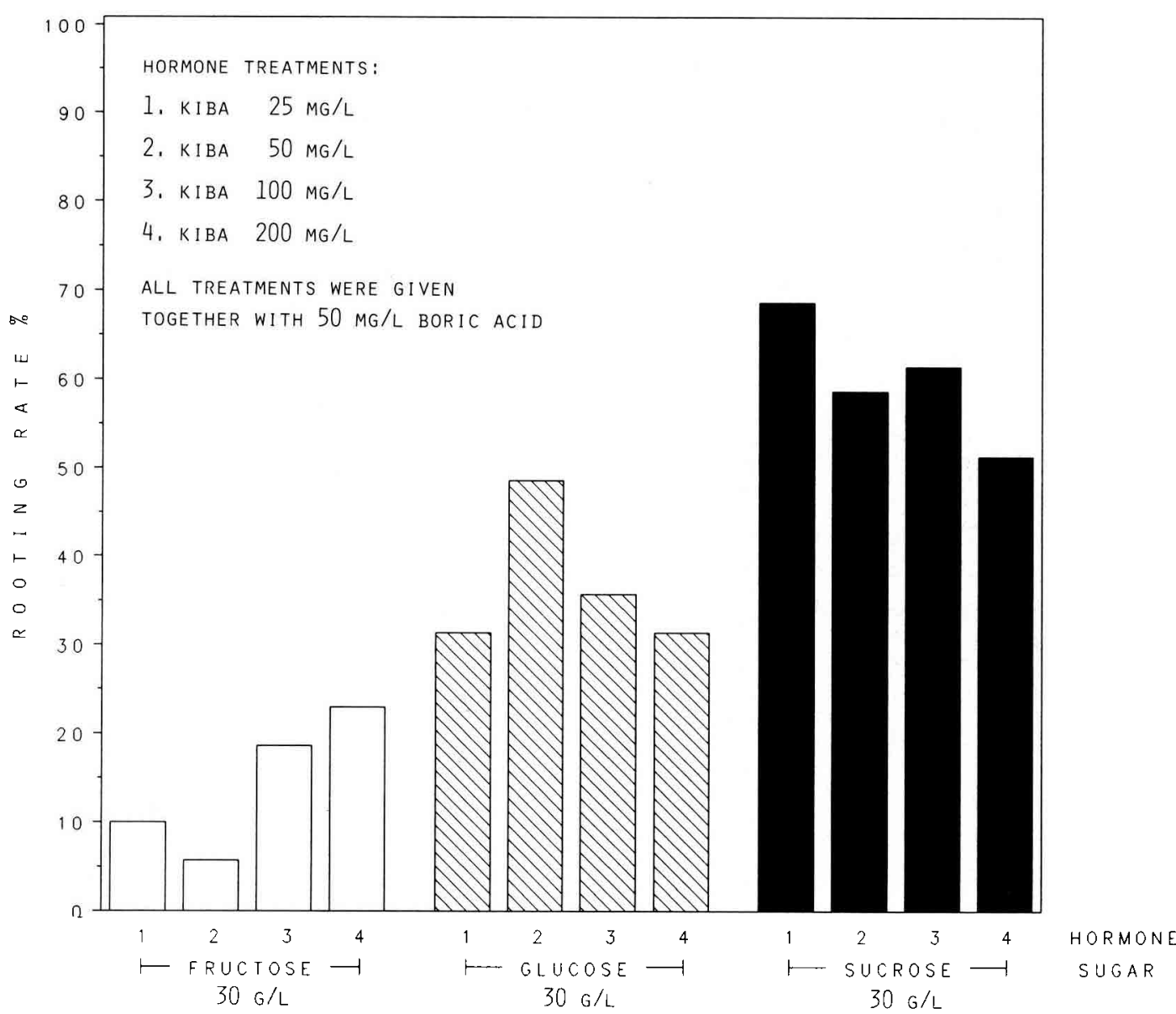

Fig 1. Effect of sugar source of the rooting medium and hormone treatments on the in vitro rooting rate of micropropagated shoots of apple rootstock YP.

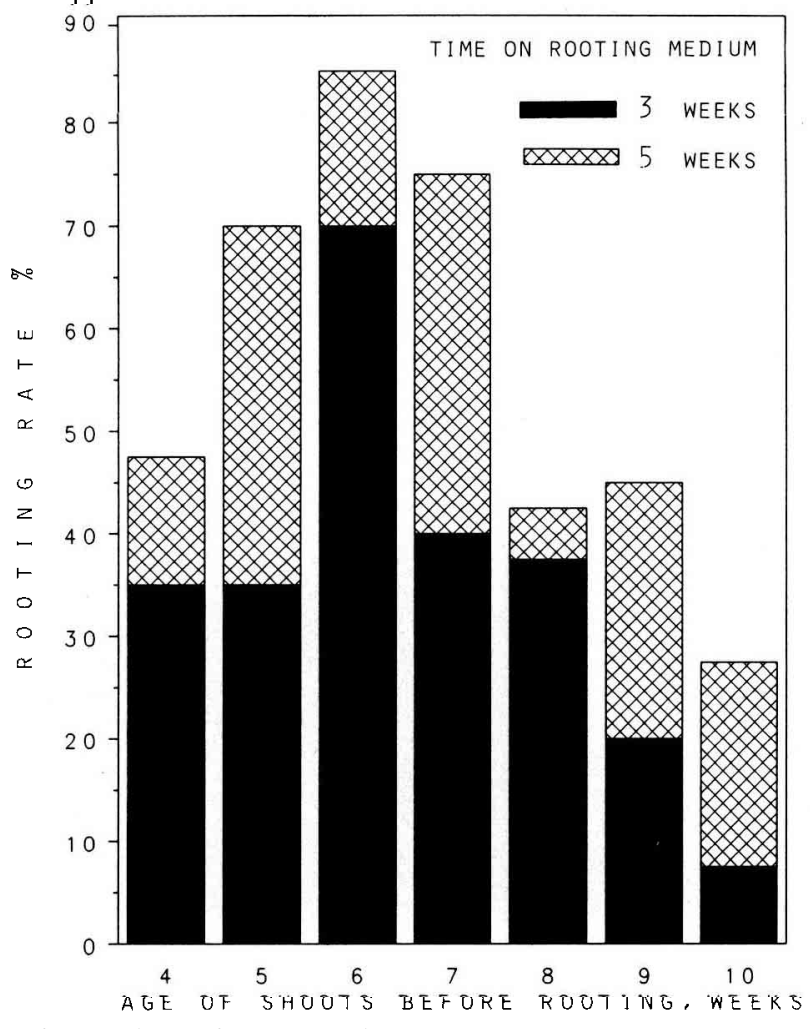

Fig 2. Effect of the age of micropropagated shoots prior to rooting on the in vitro rooting rate of apple rootstock YP after 3 and 5 weeks on rooting medium.
1988; Moncousin, 1991). The present study also showed that the optimal hormone concentration was dependent on the carbohydrate source used. This factor as well as the timing of hormone treatment require further investigation.

According to this study, one of the most critical factors in successful rooting was the developmental stage of shoots at the beginning of the rooting stage. The weaning survival and subsequent growth of the young plants were also greatly influenced by this factor. As a result of poor nutrition uptake or because of a possible hormonal inbalance, young apple plants had a tendency to lapse into arrest of growth. It was possible to overcome this problem by VAM inoculation. Light quality could also affect the rooting result. This aspect has until recently been a much-neglected topic in micropropagation research. Because apple is an economically important fruit tree, it is vital that the propagation problems are solved. Therefore the effect of light quality and particularly the utilization of VA mycorrhizas on weaning survival and subsequent growth require further investigation. 


\section{REFERENCES}

Chauvin JE, Salesses G (1988) Effet du fructose sur la micropropagation du chataignier Castanea sp. CR Acad Sci Paris 306 III, 207-212

Dirr MA, Heuser CW (1987) The Reference Manual of Woody Plant Propagation: From Seed to Tissue Culture. Varsity Press, Athens, GA, $239 \mathrm{p}$

Elliot RR (1972) Axenic culture of shoot apices of apple. $N Z J$ Bot 10, 254-258

George EF, Sherrington PD (1984) Plant Propagation by Tissue Culture. Exegetics Ltd, Edington, Westbury, $709 \mathrm{p}$

James DF, Thurbon IJ (1979) Rapid in vitro rooting of the apple rootstock M9. J Hortic Sci 54, 309-311

Moncousin C (1991) Rooting of microcuttings: general aspects. Acta Hortic 289, 301-310
Nemeth G (1986) Induction of rooting. In: Biotechnology in Agriculture and Forestry. 5. Trees /I (YPS Bajaj, ed) Springer-Verlag, Berlin, 246-286

Pua EC, Chong C (1984) Requirement for sorbitol (Dglucitol) as carbon source for in vitro propagation of Malus robusta No 5. Can J Bot 62, 1545-1549

Säkö J (1977) YP, a new clonal rootstock for apple. Ann Agric Fenn 16, 88-96

Sriskandarajah S, Mullins G (1981) Micropropagation of Granny Smith apple: factors affecting root formation in vitro. J Hortic Sci 56, 71-76

Walkey DG (1972) Production of apple plantlets from axillary bud meristem. Can J Plant Sci 52, 10851087

Yae BW, Yim YJ, Jo HM (1986) Factors effecting shoot proliferation and root initiation of the apple $\mathrm{cv}$ Fuji (Malus domestica Borkh) in vitro. J Korean Soc Hortic Sci 27, 353-358 